\title{
EXPLORING METADISCOURSE USE IN THESIS ABSTRACTS: A CROSS-CULTURAL STUDY
}

\author{
Ardi Nugroho* \\ English Language and Culture Department, Bunda Mulia University \\ Received on 2 April 2019 / Approved on 15 April 2019
}

\begin{abstract}
The use of metadiscourse in academic writing has become a topic of interest in recent years. It can be defined as the words and phrases that writers use in their writing to express their ideas and thoughts to make it easier for readers to process the information presented. It is especially crucial in academic writing since writers are expected to present their arguments in an appropriate and acceptable manner. It has also been said that culture plays a role influencing how arguments and ideas are expressed, especially in academic writing. Although metadiscourse plays an integral role in academic writing, studies have shown how EFL learners often make mistakes in employing this linguistic device. From this, the writer would like to explore the metadiscourse produced by Indonesian EFL learners and compare it with how native speakers of English employ metadiscourse in their writing. In other words, this study is basically an attempt to find out whether the metadiscourse produced by the two groups with different cultural backgrounds are different or similar. The source of data for the current study is the metadiscourse markers from the thesis abstracts of students of the English Language and Culture Department at Bunda Mulia University and American students from a university in the U.S. In order to analyze the metadiscourse markers found in the thesis abstracts of the Indonesian and American students, the writer will make use of the AntConc software version 3.5.6 by Anthony (2018). The result of the study reveals that there are some differences and similarities in the way both group of students employed these markers.
\end{abstract}

Keywords: metadiscourse, thesis abstracts, Indonesian and American students

\begin{abstract}
ABSTRAK
Penggunaan metadiscourse dalam penulisan akademik telah menjadi topik yang menarik dalam beberapa tahun terakhir. Ini dapat didefinisikan sebagai kata dan frasa yang digunakan penulis dalam tulisan mereka untuk mengekspresikan ide dan pemikiran mereka untuk memudahkan pembaca untuk memproses informasi yang disajikan. Hal ini sangat penting dalam penulisan akademik karena para penulis diharapkan untuk menyajikan argumen mereka dengan cara yang tepat dan dapat diterima. Dikatakan pula bahwa budaya memainkan peran dalam mempengaruhi bagaimana argumen dan gagasan diekspresikan, terutama dalam penulisan akademik. Meskipun metadiscourse memainkan peran integral dalam penulisan akademik, penelitian telah menunjukkan bahwa para pelajar bahasa Inggris sebagai bahasa asing (EFL) sering membuat kesalahan dalam menggunakan perangkat linguistik ini. Dari sini, penulis ingin mengeksplorasi metadiscourse yang dihasilkan oleh pelajar EFL Indonesia dan membandingkannya dengan bagaimana penutur asli bahasa Inggris menggunakan metadiscourse dalam tulisan mereka. Dengan kata lain, penelitian ini pada dasarnya merupakan upaya untuk mengetahui apakah metadiscourse yang dihasilkan oleh kedua kelompok dengan latar belakang budaya yang beda adalah berbeda atau serupa. Sumber data untuk studi ini adalah penanda metadiscourse dari abstrak tesis mahasiswa dari prodi Bahasa dan Budaya Inggris di Universitas Bunda Mulia dan mahasiswa Amerika dari universitas di AS. Dalam rangka untuk menganalisis penanda metadiscourse yang ditemukan dalam abstrak skripsi mahasiswa Indonesia dan Amerika, penulis akan menggunakan perangkat lunak AntConc versi 3.5.6 oleh Anthony (2018). Hasil penelitian menunjukkan bahwa ada beberapa perbedaan dan kesamaan dalam cara kedua kelompok siswa ini menggunakan penanda ini.
\end{abstract}

Kata Kunci: metadiscourse, abstrak tesis, mahasiswa Indonesia dan Amerika

\footnotetext{
*Author(s) Correspondence:

E-mail: anugroho@bundamulia.ac.id
} 


\section{INTRODUCTION}

\subsection{Background of the Study}

The use of metadiscourse in academic writing has become a topic of interest in recent years. Metadiscourse itself can be defined as “... the linguistic devices writers employ to shape their arguments to the needs and expectations of their target readers" (Hyland, 2004). In other words, it is the words and phrases that writers use in their writing to express their ideas and thoughts to make it easier for readers to process the information presented. It is especially crucial in academic writing since writers are expected to present their arguments in an appropriate and acceptable manner.

There have been numerous studies on this topic, such as the one by Khedri, Heng and Ebrahimi (2013) which explores the use of interactive metadiscourse markers in research article abstracts from two disciplines. Another study also investigates metadiscourse in research abstracts, but compares those written by Turkish and American postgraduate students (Ozdemir and Longo, 2014). Besides the use of metadiscourse in research abstracts, a study by Gholami, Nejad, and Pour (2014) examines how EFL learners misuse metadiscourse markers in their argumentative essays. Although various studies concerning metadiscourse have been conducted, little research has been carried out where the object is abstracts written by Indonesian EFL learners. Hence, the writer has become interested in investigating how EFL students, more specifically students from the English Language and Culture Department at Bunda Mulia University, make use of metadiscourse markers in their thesis abstracts and compares it with those written by native speakers of English.

\subsection{Statement of Problem and Research Questions}

As has been described above, metadiscourse is a very important element in academic writing. It serves as a tool to show a writer's position regarding a particular topic while also attempting to build a relationship with readers (Hyland, 2004). That is to say, metadiscourse is used to reflect how strongly a writer would like to express a particular proposition. It can also be used to help readers understand the information presented by writers as proper use of this linguistic device can help organize ideas in an orderly manner.

Nonetheless, although metadiscourse plays an integral role in academic writing, studies have shown how EFL learners often make mistakes in employing this linguistic device (Gholami, Nejad, and Pour, 2014). This might also be the case for Indonesian learners of English, seeing as it is generally difficult for students to appropriately and accurately express their ideas and opinions in English, especially in formal academic writing. However, the current study does not focus on the mistakes made by Indonesian students but merely explores the metadiscourse produced by them and compares it with how native speakers of English employ metadiscourse in their writing. More specifically, the writer would like to see whether there is a significant difference between how nonnative and native speakers of English, i.e. American students, make use of metadiscourse markers in their thesis abstracts. Based on this, the following research questions are proposed:

1) How does the use of metadiscourse markers produced by Indonesian EFL learners compare with the use of metadiscourse markers produced by American students?

2) Which of the two types of metadiscourse markers, namely textual and interpersonal, is more frequently found in the thesis abstracts of both groups of students?

\subsection{Research Objective}

This study aims to compare the use of metadiscourse markers in undergraduate thesis abstracts made by nonnative speakers of English, i.e. Indonesian EFL learners, and American students. It has been said that culture plays a role in influencing how arguments and ideas are expressed, especially

\footnotetext{
*Author(s) Correspondence:

E-mail: anugroho@bundamulia.ac.id
} 
in academic writing. Therefore, this study is basically an attempt to find out whether the metadiscourse produced by the two groups with different cultural backgrounds are different or similar.

\subsection{Significance of the Study}

The significance of the study lies in the information regarding the difference in the use of metadiscourse by nonnative and native speakers of English. It is important to explore this as metadiscourse itself is a very vital element of academic writing, and if it is found that there is indeed a difference in the use of metadiscourse, then it would be imperative that readers be made aware of this, so that future usages of metadiscourse markers would appropriately reflect the cultural background of the writer. Moreover, it is also hoped that the result of this study would some shed light into the topic of metadiscourse markers in general.

\section{THEORETICAL FRAMEWORK}

\subsection{Previous Studies}

In the past few years, several studies regarding metadiscourse markers have been done. Three of these studies have been briefly mentioned in the previous chapter. In this section, these three researches are going to be described in more detail. Firstly, Gholami, Nejad, and Pour (2014) conducted a research on how Iranian EFL students made mistakes in their use of metadiscourse markers in their argumentative essays. The result shows that the misuse of metadiscourse markers is due to their overuse, punctuation, interlingua and intralingua errors. Moreover, the relation between the students' TOEFL score and essay score is also analyzed, and it is found that there is a positive correlation between the two variables. To be precise, the students' overall language proficiency proved to be closely related with their ability to use metadiscourse markers in their essays. The higher the TOEFL score, the better the students are at appropriately employing the metadiscourse markers in their writing, and vice versa.
The second study by Khedri, Heng and Ebrahimi (2013) examined how students from two disciplines, i.e. Applied Linguistics and Economics, made use of interactive discourse markers in their research abstracts. Based on their findings, it is revealed that there is indeed a difference in the number of markers used in each discipline. More specifically, the students from the Applied Linguistic major employed more metadiscourse markers overall compared to the students from the Economics major. This supports the claim that specific disciplines and fields of study have their own norms for presenting arguments, which leads to the different usages of metadiscourse markers in their academic writings.

Lastly, Ozdemir and Longo (2014) conducted a study on the use of metadiscourse produced by Turkish and American postgraduate students in their master thesis abstracts. The result indicates that evidential, endophorics, code glosses, boosters, attitude markers, self-mentions are used less by the Turkish students compared to the American ones. In contrast, the Turkish students employed more metadiscourse transitions, frame markers and hedges in their writings. This result shows that culture does indeed affect the way writers present their arguments in academic writings.

To summarize, the three previous studies described above all deal with the topic of metadiscourse markers in academic writing. The first is concerned with its misuse by nonnative speakers of English, the second is related with its use in different disciplines, and the last deals with its use by students from different cultural backgrounds. The present study is quite similar with the last one in the sense that it also explores the use of metadiscourse markers made by students from different cultural backgrounds, but the current one compares Indonesian students and American students.

\subsection{Academic Discourse}

Before going into more detail about metadiscourse markers, it would be better to briefly look into the characteristics of

\footnotetext{
*Author(s) Correspondence:

E-mail: anugroho@bundamulia.ac.id
} 
academic discourse and why it is closely related to metadiscourse. As we all know, academic texts are in general very formal in nature and involves scientific arguments and propositions. In other words, compared to other kinds of writings or texts, academic ones commonly use formal language, which means slangs and contractions are not typically allowed. Additionally, the information presented in these academic texts are normally based on scientific evidence and not just based on personal opinions and thoughts. Furthermore, Hyland (2011) proposes several characteristics of academic discourse as follows:

1) academic texts are commonly persuasive in nature

2) arguments in academic texts are usually presented in manners specific to a particular field of study

3) different cultures have different ways of expressing ideas and arguments in academic texts

4) presenting academic arguments involve interpersonal negotiations between the writer and the reader

From the explanations above, it can be seen that academic texts have some very specific characteristics which differentiate them from other texts. First of all, writers of academic texts usually try to persuade the readers to agree with the arguments which are presented. Next, these arguments are normally presented following the norms of particular fields of study. For instance, writers in the field of economics would most likely present their arguments in a different manner compared to writers in the field of biology. Other than the different field of study, culture also plays a role in determining how one expresses ideas and thoughts. Lastly, when presenting the academic arguments, a negotiation between writer and reader must happen in the sense that the writer must consider the reader to ensure that the message is clearly transferred from writer to reader.

Based on the description above, it is clear that academic discourse are indeed very important and closely related to metadiscourse markers as it involves the way writers propose their ideas and arguments. Not only that, metadiscourse markers can also help organize ideas in such a way that readers would be able to easily follow the writer's train of thoughts while at the same time feel involved in some way.

\subsection{Metadiscourse Markers}

After briefly looking at the characteristics of academic discourse, let us now take a look at some definitions of metadiscourse as well as some of its categorizations. First of all, Hyland (2000, as cited in Hyland and Tse, 2004) defines metadiscourse as "... the linguistic resources used to organize a discourse or the writer's stance towards either its content or the reader. Additionally, Schiffrin (1980, as cited in Hyland and Tse, 2004) is of the opinion that "metadiscourse is more generally seen as the author's linguistic and rhetorical manifestation in the text in order to bracket the discourse organisation and the expressive implications of what is being said." From these definitions, it can be concluded that metadiscourse markers deal with linguistic devices used by writers to express and organize their ideas and arguments in such a way that also consider the readers.

$$
\text { Furthermore, Hyland }
$$

categorizes metadiscourse into two types, namely textual and interpersonal metadiscourse. Textual metadiscourse deals with the organization of ideas so that they are presented in a coherent manner. On the other hand, interpersonal metadiscourse involves the way writers express their arguments and how they expect the readers to understand and accept them. The summary of these two types along with the sub-classes for each are presented in the table below:

\footnotetext{
*Author(s) Correspondence:

E-mail: anugroho@bundamulia.ac.id
} 
Table 1. Metadiscourse Schemata for Academic Texts

\begin{tabular}{|c|c|c|}
\hline Category & Function: & Examples/signals \\
\hline \multicolumn{3}{|l|}{ Textual metadiscourse } \\
\hline Logical connectives & $\begin{array}{l}\text { express semantic relation } \\
\text { between main clauses }\end{array}$ & in addition/but/therefore/thus \\
\hline Frame markers & $\begin{array}{l}\text { explicitly refer to discourse } \\
\text { shifts or text stages }\end{array}$ & first/finally/to repeat/to clarify \\
\hline Endophoric markers & $\begin{array}{l}\text { refer to information in other } \\
\text { parts of the text }\end{array}$ & $\begin{array}{l}\text { noted above/see Fig. 1/section } \\
2\end{array}$ \\
\hline Evidentials & $\begin{array}{l}\text { refer to source of information } \\
\text { from other texts }\end{array}$ & according to X/Y, $1990 / Z$ states \\
\hline Code glosses & $\begin{array}{l}\text { help readers grasp meanings } \\
\text { of ideational material }\end{array}$ & $\begin{array}{l}\text { namely/e.g./in other } \\
\text { words/i.e./say }\end{array}$ \\
\hline \multicolumn{3}{|l|}{$\begin{array}{l}\text { Interpersonal } \\
\text { metadiscourse }\end{array}$} \\
\hline Hedges & $\begin{array}{l}\text { withhold writer's full } \\
\text { commitment to statements }\end{array}$ & might/perhaps/it is possible \\
\hline Emphatics & $\begin{array}{l}\text { emphasise force or writer's } \\
\text { certainty in message }\end{array}$ & in fact/definitely/it is clear \\
\hline Attitude markers & $\begin{array}{l}\text { express writer's attitude to } \\
\text { propositional content }\end{array}$ & surprisingly/I agree/X claims \\
\hline Relational markers & $\begin{array}{l}\text { explicitly refer to or build } \\
\text { relationship with reader }\end{array}$ & $\begin{array}{l}\text { consider/recall/imagine/you } \\
\text { see }\end{array}$ \\
\hline Person markers & explicit reference to author(s) & I/we/my/mine/our \\
\hline
\end{tabular}

Taken from Hyland (1999)

\section{RESEARCH METHOD}

\subsection{Source of Data}

The source of data for the current study is the thesis abstracts from students of the English Language and Culture Department at Bunda Mulia University and the English Department at the University of Notre Dame in the U.S. To be exact, the data is the metadiscourse markers found in the abstracts of these two groups of students with different cultural backgrounds. The markers will include both categories proposed by Hyland (1999), namely textual and interpersonal metadiscourse markers. Both are from the English department to ensure that the comparison is more or less equal as previous studies have shown that different fields of study may result in different usages of metadiscourse markers. Moreover, the reason why the writer limits the source of data to only the thesis abstracts is because of the time limitation of the research, as well as the availability of the thesis abstracts from the American students. In other words, the abstract section is the only part of the American students' thesis that can be readily and freely accessed by the writer. Furthermore, the thesis abstracts collected are limited to those from the students from the year 2016 until 2018 for the nonnative abstracts and from the years 2015, 2017 and 2018 for the native ones. A total of 34 abstracts are used as the source of data, 20 are the Indonesian students' abstracts and 14 are from the American students. From these amounts, the abstracts are randomly taken from the previously mentioned years. For instance, for the nonnative abstracts, 7 are randomly taken from the year 2016, 7 from 2017, and 6 from 2018. Last but not least, the reason why the total number of abstracts is not equal between the nonnative and native students is because the average number of words for the American students' abstracts is somewhat higher than the Indonesian students'

\footnotetext{
*Author(s) Correspondence:

E-mail: anugroho@bundamulia.ac.id
} 
abstracts. In other words, the American students' abstracts are longer compared to the Indonesian students'. In order to ensure a more balanced comparison of the two groups, the total amount of words is used as the main parameter. To be more precise, there are approximately 3,885 words in the American students' abstracts and 3,850 words in the Indonesian students' abstracts.

\subsection{Research Instrument}

In order to analyze the metadiscourse markers found in the undergraduate thesis abstracts of the Indonesian and American students, the writer will make use of the AntCone software version 3.5.6 by Anthony (2018). This is a freeware corpus analysis toolkit that can be used to analyze various texts. Of course since this study is limited to analyzing the metadiscourse markers used by the two groups of students, the software would only be used to list all of the markers along with their frequency.

\subsection{Data Collection Procedure}

The data collection procedure basically involves two steps. The first is to collect the thesis abstracts from both groups of students, and the last step is to save all of those abstracts into the txt format. This is necessary as the AntConc software can only process files with that particular format or extension.

\subsection{Data Analysis Procedure}

After collecting all of the thesis abstracts from the nonnative and native students of English and saving all of the files into the txt format, we can then input those files into the AntConc software to be analyzed. To analyze the abstracts, we simply need to look at the word list result from the software. From that word list, the writer identifies and categorizes the metadiscourse markers based on the two categories, i.e. textual and interpersonal. After categorizing the metadiscourse markers, the next step of analysis is to examine the difference between the markers used by the Indonesian and American students. Lastly, the two types of markers are further analyzed to see which of the two are more frequently employed by each group of students.

\section{FINDINGS AND DISCUSSIONS}

\subsection{Findings}

For starters, as has been mentioned in the previous section, a total of 20 abstracts from the Indonesian students and 14 from the American students are used as the data for the current study. The Indonesian students' abstracts have approximately 3,850 words in total, whereas the American students' abstracts have 3,885 words. From these amounts, the nonnative students' abstracts have 863 word types, while the native students' abstracts have 1,372 word types. The difference between the two is quite big, i.e. more or less 500 word types. This shows that the American students are somewhat more creative in their writing as they utilized a wider array of lexical items compared to the Indonesian ones. This may be due to the Indonesian students' lack of vocabulary, or it can be said that the nonnative students have an overall lower vocabulary size in comparison to the native students.

Now let us take a look at the metadiscourse markers. There are two types which have become the focus of this research, namely textual and interpersonal. Furthermore, Hyland (1999) categorizes each into more specific classifications, i.e. logical connectives, frame markers, endophoric markers, evidentials and code glosses for the textual metadiscourse and hedges, emphatics, attitude, relational, and person markers for the interpersonal metadiscourse. The sections below elaborate on the use of these markers by both nonnative and native students.

\subsubsection{Nonnative Students' Metadiscourse Markers \\ First of all, we are going to examine} the nonnative students' production of metadiscourse markers in their thesis abstracts. Based on the previously mentioned categorization, it is found that the students employed some textual and interpersonal markers in their writing. Each of these markers

\footnotetext{
*Author(s) Correspondence:

E-mail: anugroho@bundamulia.ac.id
} 
is described below along with some example sentences in which they appear.

\section{A) Textual Metadiscourse}

\section{a) Logical Connectives}

From the data, it is found that the Indonesian students used 5 (five) logical connectives as follows:

1) moreover

5
3
2
2
1

2) furthermore

3) therefore

4) but

5) in addition

Logical connectives basically serve as a connection between clauses. The connection can be in the form of addition, contradiction, cause and effect, etc. Here the students mostly employed the word moreover (5 times) to connect two sentences with the purpose of adding more information. The least logical connective produced by the students is the phrase in addition (1 time), which essentially has the same function as the word moreover. Some example sentences can be seen below:

- ... videos were used based on their functions mentioned in the theories. Moreover, it is concluded that each grammatical feature ...

- $\quad .$. the index of source text and target text has different result. Moreover, the result according to the readers in the questionnaire ...

- ... euphemism can be done through context. In addition, writer also find 5 types of euphemisms used ...

Besides adding more information, the word therefore is also used to connect two sentences which have a cause and effect relation. The following are two example sentences with this word:

- ... designed to deliver a glimpse of fear to the people. Therefore, in this research, the writer conducted a research ...

- ... which lead them into the production of errors. Therefore, it lead the researcher to conduct the research ...

Lastly, the word but is also used twice by the students to indicate a relation of contradiction as can be seen in the sentences below:

- ... transfers one sentence from one language to another verbally. But, being an interpreter is not an easy job ...

- $\quad \ldots$ and to express the no sense of obligation but, the rights that is containing the context of the sentences $\ldots$

It is clear that between the first sentence / clause and the next, the two contradict or oppose one another. Hence, the students utilized this word appropriately.

b) Frame Markers

Frame markers can be used to signal a move in a particular discourse or to refer to a specific part in a piece of writing. The data shows that the students produced 3 (three) of these, namely:
1) finally
2
2) next
2
3) first

The students basically employ frame markers when they want to move from one idea to the next and to signal the order in which said idea appears. For example, they used finally to signal that it is the last, or next to signal an additional one, etc. Some example sentences are as follow:

- ... one was used the most by the Jakarta Post. Finally, writer also found out that there are 6 categories ...

- ... two different tests in different day to the students regarding the reported speech. Next, the researcher will sort out the common tenses error ...

- ... Several steps are conducted to get the result of this research. First, the researcher gave two different tests in different day to the students ...

*Author(s) Correspondence:

E-mail: anugroho@bundamulia.ac.id 
c) Evidentials

The third type of textual metadiscourse marker found in the students' abstracts is evidentials, which are normally used when the students quote or refer to information from experts. The students only came up with the following 2 (two):

1) according to 3

2) stated 2

Since this marker is commonly used to quote someone, the marker is generally found near an expert's name. This is quite apparent in the following sentences:

- ... According to Kaisa Koskinen the direct transfer, omission, or replacement can refers to the translator's textual visibility ...

- ... the theory of adaptation by Geoffrey Wagner that stated three types transition of adaptation and to analyze ...

\section{d) Code Glosses}

This type of marker is supposed to assist the readers in identifying examples or when the writer is explaining something in another way. The data reveals that the students did not use them too often, i.e. only twice. The two code glosses employed by the students are:
1) for example
1
2) for instance
1

Both of these expressions deal with giving examples. They are normally found at the beginning of the sentence right before the example itself as can be seen in the sentences below:

- ... using the digital media such as a film. For example like the novel by Dan Brown's "Inferno" to the film with a same title ...

- ... The slang usage that people used could be various. For instance, Allan used the slang expression buddy to show ...

\section{B) Interpersonal Metadiscourse}

a) Hedges

Hedges can be used to lower the degree of certainty of a writer's proposition. In other words, when a writer is not fully confident of a particular statement, he or she may utilize this kind of metadiscourse marker. The words that fall into this category are usually modals such as may, might, could, etc. Based on the data, only 1 (one) word is used, but it is found 6 times in the students' abstracts. The word is:
1) could
6

In all 6 instances in which could is used, the function is to lower the strength of the statement. That is to say, the writer takes a position where he or she may not be fully confident of his or her proposition, so a modal is used to make the statement less certain. The example sentences are as follow:

- ... the effect towards viewers where there could be a possibility of a misunderstanding in the implied word ...

- ... However, language could give a different interpretation to the hearers $\cdots$

- ... This condition, which usually called as 'ambiguous' could occurred in both of spoken and written form ...

b) Emphatics

The next interpersonal metadiscourse that can be found in the students' abstracts is emphatics. Contrary to hedges, this marker's function is to emphasize a writer's certainty of a particular proposition. In other words, this marker is used to strengthen a statement as the writer is most likely very confident of his or her claim. Nevertheless, only 1 (one) marker of this type is found in the data, which is:
1) clearly 1

This word can be found in the following sentence:

- ... the setting of the novel also portrayed the racism that still happen in South American during the early

*Author(s) Correspondence:

E-mail: anugroho@bundamulia.ac.id 
nineteenth century which is why the racism aspect can be seen clearly ...

From the sentence above, we can see that the word clearly is used to emphasize the certainty of the statement. The writer most likely included this word in the sentence to highlight the topic of racism.

\section{c) Attitude Markers}

When this kind of marker is used, it usually reflects a writer's feelings or opinions towards a certain proposition. Not many of this kind are found in the students' abstracts, more specifically, only 2 (two) words. They are:
1) suddenly
2
2) hopefully
1

The word suddenly is most likely used to show the writer's surprise or something that is unexpected, while the word hopefully probably indicates that the writer would like something to happen in the future. The sentences with these words can be seen below:

- $\quad .$. The aim of this research is also to figure out what is the function of 'shall' which suddenly appears in the translation of the target language ...

- ... determine the meaning of the word given. Hopefully, this research will provide explanation about ...

\section{d) Person Markers}

The last interpersonal metadiscourse discussed is the most frequent one found in the data. There is a total of 48 (forty eight) person markers in the students' abstracts. Even though this marker is often found in the data, there are actually only 2 (two) words that can be considered a person marker. These are:
1) researcher
36
2) writer
12

These two words basically refer to the same person, i.e. the students who wrote the thesis. Two different words are used probably with the purpose of avoiding repetition. Some sentences in which these words appear are as follow:
- ... students' perception of the use of role play. The researcher analyzes and interpret the data questionnaire using the likert scale ...

- ... First, the researcher gave two different tests in different day to the students ...

- ... The result that writer found was interpretation of euphemism can be done through context ...

- ... Finally, writer also found out that there are 6 categories where euphemisms were found the most ...

\subsubsection{Native Students' Metadiscourse Markers}

Now we are going to look into how the native students employed both textual and interpersonal metadiscourse in their thesis abstracts. Just as the previous section, each of the types is going to be described briefly, followed by example sentences containing the markers.

\section{A) Textual Metadiscourse}

a) Logical Connectives

For the first textual marker, it is found that there are 3 (three) logical connectives employed by the native students in their thesis abstracts. These three words are used 12 times in total as follow:
1) but 7
2) thus 3
3) moreover 2

These three words have different functions. The first word but deals with contradiction, the second word thus talks about result, and lastly moreover is concerned with additional information. Some of the example sentences can be seen below:

- ... a shorthand that fits nicely on our modern bipolar political spectrum, but is not particular useful for understanding Pound's philosophical complexities ...

- ... in a culture which is fundamentaJly exploitative. Thus, they argue that we must change the system ...

\footnotetext{
*Author(s) Correspondence:

E-mail: anugroho@bundamulia.ac.id
} 
- ... cases may all be viewed as elements of spiritualism. Moreover, the methods Sherlock Holmes uses when solving problems ...

b) Frame Markers

The next marker that the students produced falls under the category of frame markers. There are 4 (four) words, and they appear 7 times overall. The words are:

1) first

2) second 3

3) third 2

4) fourth

Since the frame markers that are used are words dealing with sequence, i.e. first, second, third and fourth, their purpose is to signal the order in which the information appear. The example sentences are as follow:

- ... This paper first examines the roles and experiences of the main female characters in the novel ...

- ... as a pulse and rhythm, as in jazz; second, 'beat' as a condition of being outcast, marginalized ...

- ... encourages sympathy, understanding, and human connection; fourth, and most profoundly, 'beat' as in beatitude...

\section{B) Interpersonal Metadiscourse}

a) Hedges

Next, we shall examine the interpersonal metadiscourse markers. The first one is hedges. Several of them have been found in the native students' abstracts, 4 (four) words to be exact. These words include:

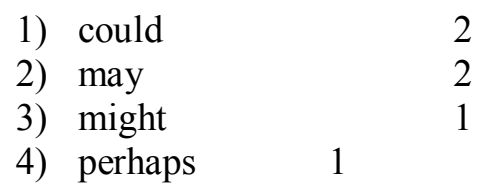

Similar to the nonnative students, the native ones utilized these words when they want to lower the certainty level of their statement, most likely because they are not fully confident of the message they want to convey. The sentences below exemplify this:

*Author(s) Correspondence:

E-mail: anugroho@bundamulia.ac.id

- ... the potential for other fruitful readings that could move criticism in new directions ...

- ... the mystery of those crime cases may all be viewed as elements of spiritualism ...

- ... both Samson and Springsteen truly capture what is perhaps the most natural and familiar feeling in the world ...

b) Emphatics

Emphatics is the second interpersonal metadiscourse marker that can be found in the data. Nonetheless, only 1 (one) phrase is used and only once. The phrase is as follows:

1) in fact

1

As has been previously discussed, this kind of marker is the opposite of hedges, where it functions as an emphasis towards a writer's proposition. Based on the data, the only emphatics used is the phrase in fact. The following sentence shows how this phrase strengthens the force of the message:

- ... There are two questions I examined in this thesis. In fact, Holmes' rejection of the supernatural does not necessarily mean that elements of spiritualism cannot be seen in this character ...

\section{c) Attitude Markers}

The next marker that is reviewed is the attitude marker. From the data, only 1 (one) word falls under this category, which is:

1) hope 1

The word hope here most likely reflects the writer's feelings that he or she would like something to happen in the near future. The following is the sentence containing said word:

- ... With this lesson plan, I hope to foster a professional discussion on education ...

\section{d) Person Markers}

The last marker discussed in this section is the person markers. Based on the data, only 2 (two) words are found that can be 
classified as this kind of interpersonal metadiscourse marker. The following are the two words:
1) I
11
2) my
7

As the name suggest, person markers refer to the writer or the student who wrote the abstract. Therefore, the word $I$ here refers to the writer itself and the word $\boldsymbol{m y}$ denotes something belonging to the writer. Some example sentences in which these words appear are presented below:

- ... the Green World of The Tempest is also unconventional. I argue that Prospero uses the knowledge of and power over ...

- ... the objectification and denial of agency of Miranda. $\underline{\mathbf{I}}$ conclude that in order for criticism of The Tempest to do justice to such a multifaceted play ...

- ... Conan Doyle was on the latter side. My central argument is that, if spiritualism is interpreted as an extension of science ...
- ... The progression of these senses of 'beat' confirms a movement toward religious illumination and fulfillment that, in my view, is central to the poem $\ldots$

\subsection{Discussion}

After briefly reviewing the metadiscourse markers employed by both nonnative and native students in their thesis abstracts along with how they are used in sentences, we shall now discuss the findings in more detail, more specifically, the research questions of the current study are going to be answered and elaborated. For starters, the first research question is concerned with comparing the metadiscourse used by both groups of students with different cultural background. To be exact, the nonnative students are from Indonesia, and the native students are from the United States. To answer this first question, let us take a look at the following table:

Table 2. Metadiscourse Markers of Nonnative and Native Students

\begin{tabular}{|c|c|c|c|c|c|}
\hline \multicolumn{2}{|c|}{ Metadiscourse } & \multicolumn{2}{|c|}{ Nonnative } & \multicolumn{2}{|c|}{ Native } \\
\hline \multirow{16}{*}{ Textual } & \multirow{6}{*}{$\begin{array}{l}\text { Logical } \\
\text { Connectives }\end{array}$} & moreover & 5 & thus & 7 \\
\hline & & furthermore & 3 & but & 3 \\
\hline & & therefore & 2 & moreover & 2 \\
\hline & & but & 2 & - & - \\
\hline & & in addition & 1 & - & - \\
\hline & & Total & 13 & Total & 12 \\
\hline & \multirow{5}{*}{$\begin{array}{l}\text { Frame } \\
\text { Markers }\end{array}$} & finally & 2 & first & 3 \\
\hline & & next & 2 & second & 2 \\
\hline & & first & 1 & third & 1 \\
\hline & & - & - & fourth & 1 \\
\hline & & Total & 5 & Total & 7 \\
\hline & $\begin{array}{l}\text { Endophoric } \\
\text { Markers }\end{array}$ & - & - & - & - \\
\hline & \multirow{3}{*}{ Evidentials } & according to & 3 & - & - \\
\hline & & stated & 2 & - & - \\
\hline & & Total & 5 & Total & $\mathbf{0}$ \\
\hline & Code Glosses & for example & 1 & - & - \\
\hline
\end{tabular}

*Author(s) Correspondence:

E-mail: anugroho@bundamulia.ac.id 


\begin{tabular}{|c|c|c|c|c|c|}
\hline & & for instance & 1 & - & - \\
\hline & & Total & 2 & Total & $\mathbf{0}$ \\
\hline & al Textual $\mathrm{N}$ & & 25 & & 19 \\
\hline & & could & 6 & could & 2 \\
\hline & & - & - & may & 2 \\
\hline & Hedges & - & - & might & 1 \\
\hline & & - & - & perhaps & 1 \\
\hline & & Total & 6 & Total & 6 \\
\hline & Fmnhatics & clearly & 1 & in fact & 1 \\
\hline & & Total & 1 & Total & 1 \\
\hline Interpersonal & & suddenly & 2 & hope & 1 \\
\hline & Alitude & hopefully & 1 & - & - \\
\hline & & Total & 3 & Total & 1 \\
\hline & $\begin{array}{l}\text { Relational } \\
\text { Markers }\end{array}$ & - & - & - & - \\
\hline & & researcher & 36 & I & 11 \\
\hline & Corlanc & writer & 12 & my & 7 \\
\hline & & Total & 48 & Total & 18 \\
\hline Tota & nterperson: & kers & 58 & & 26 \\
\hline & Total & & 83 & & 45 \\
\hline
\end{tabular}

From the table above, it can be seen that there are several differences between the metadiscourse markers utilized by the nonnative and native students. Firstly, in terms of overall total, it would seem that the nonnative students used more metadiscourse markers compared to the native ones, that is 83 and 45 respectively. This difference is quite big, almost twice as many. Not only overall total, but the nonnative students came up with 18 different words, whereas the native ones only produced 15 . This shows that Indonesian students tend to use more of these markers in their abstracts, perhaps to help the readers understand their writing better or to organize the information presented in the abstract more clearly.

Second, one of the main reason there is a rather big gap between the amount of markers from the nonnative and native students is that the latter group did not employ as many person markers as the first group. The nonnative students used 48 , while the native ones only utilized 18 . Based on this result, it can be said that the Indonesian students often referred to themselves in their abstracts, meaning that they still somewhat highlighted the role of the writer in the research. Normally, it would be best to emphasize more on the research itself rather than the person doing it. That is why in academic writing, sentences are also often constructed in passive voice so that the focus is more on the research being conducted. Furthermore, it is important to note that the words both groups used are very different from each other. The nonnative group used the words researcher and writer, while the latter group wrote the pronouns $\boldsymbol{I}$ and $\boldsymbol{m y}$. This is perhaps due to the difference in culture. In Indonesia, it is suggested that if the person doing the research were to refer to himself or herself, it would be best to use the words writer or researcher to keep the tone of the writing formal. However, it would seem that this is not the case for the American students. It is possible that they were taught differently, more specifically, they might have been told that it is alright to use pronouns such as $\boldsymbol{I}$ and $m \boldsymbol{m}$ to refer to themselves.

*Author(s) Correspondence:

E-mail: anugroho@bundamulia.ac.id 
The last thing worth noting in regards to the differences between the two groups is that the Indonesian students produced some evidentials and code glosses, whereas the Americans did not. Even though the frequency is not that many, 5 and 2 respectively, this still shows that even in abstracts, the former group still included quotations from experts and provided examples to support their arguments. On the other hand, the latter group did not include such information in their abstracts. This difference may also be a result of difference in culture and habit. Perhaps in the U.S. the students are taught to keep their abstracts concise and only include information that is really important and necessary. However, in Indonesia, more specifically in Bunda Mulia University, the students are taught to include any kind of information, as long as it helps support and explain the thesis more clearly.

Beside some of the differences that have been discussed above, the nonnative and native students share some similarities in their production of metadiscourse markers. The most apparent one is that both groups of students did not make use of any endophoric and relational markers. A possible reason for this is the nature of an abstract itself. Endophoric markers deal with referring to information in other parts of the text, but since an abstract is short and only provides crucial details that summarizes a study, it is most likely not necessary to use expressions such as see this figure or noted above which are examples of this kind of marker. As for the relational marker, perhaps it is also not found in the data because this kind of marker is most likely to be found in the introduction or discussion section of a thesis as the function is to build a relationship with the reader. Of course, in a short abstract, this kind of things is probably not essential, and thus, neither the nonnative nor native students used this in their abstracts.

Lastly, something that both groups of students have in common is the fact that some of the markers' frequency is quite similar. For example, the nonnative and native students have 13 and 12 logical connectives respectively, or 5 and 7 for the frame markers, as well as the exact amount for the hedges and emphatics. This goes to show that even though the students have different cultural backgrounds and may have been taught differently, the norms for writing an abstract for a thesis are still more or less alike.

Moving on to the second and final research question, in terms of which of the two metadiscourse marker is more frequently found in the abstracts of both Indonesian and American students, the answer is the same for both groups. To be precise, both the nonnative and native students employed more interpersonal metadiscourse markers. The nonnative students used 58, and the native produced 26 markers in total. In contrast, the total for the textual metadiscourse markers is only 25 and 19 for the Indonesian and American students respectively. Thus, it can be assumed that interpersonal metadiscourse markers are perhaps a more essential part of abstracts compared to textual ones. Of course, this can again be attributed to the nature of an abstract, where since it is short and concise, there is less need for words or phrases that refer to other parts of the text, or give the sequence of the information presented, etc., which are essentially the main functions of textual metadiscourse markers.

Finally, it is also worth mentioning that even though the total is higher for the interpersonal marker, this is mainly due to the high frequency of the person marker. If this marker was not used so often, perhaps the textual one might have been the dominant marker found in the abstracts since both nonnative and native students utilized quite a lot of logical connectives (13 and 12) in their abstracts. In other words, although the other textual markers are not used too frequently by the students, the logical connective marker is still a rather essential element of an abstract as it is needed to organize the information presented. Without the inclusion of this marker, an abstract would most likely be quite difficult to follow and understand. Hence, words like moreover, therefore, but, etc. are still quite necessary to show the semantic relation between clauses or sentences.

\footnotetext{
*Author(s) Correspondence:

E-mail: anugroho@bundamulia.ac.id
} 


\section{CONCLUSION AND SUGGESTION}

\subsection{Conclusion}

In the previous section, we have examined and discussed the findings of this study. As a conclusion, the answer to the two research questions is going to be briefly reviewed and summarized in this section. Based on the data and discussion, it can be concluded that although there are some differences in the way nonnative (Indonesian) and native (American) students employed both textual and interpersonal metadiscourse markers in their thesis abstracts, there are also some similarities. In terms of differences, one of the most significant differences worth noting is the amount of markers used by both groups. The Indonesian students produced almost twice as many markers compared to the American students. This indicates that the nonnative students are concerned with using these linguistic devices to organize the information or message that they would like to convey. It is also possible that they use more markers than the American students because they also try to build a relation with the readers. The last difference that should be highlighted deals with the person marker. The nonnative students used words like researcher and writer, while the American students produced the pronouns $\boldsymbol{I}$ and $\boldsymbol{m y}$ to refer to themselves. This probably reflects the difference in habit and the way they were taught.

For the similarities, both group of students used similar number of specific types of markers. For instance, they both used interpersonal metadiscourse markers more than the textual ones. The total for some of the markers such as logical connectives and frame markers are also alike. Lastly, both Indonesian and American students did not utilize any endophoric and relational markers in their thesis abstracts. Perhaps it is because of the nature of an abstract that these two types ended up not being used at all by either group of students.

To sum up, it can be said that the difference in cultural background and perhaps even different teachings that the students received may have partly influenced the way these two groups produced metadiscourse markers in general. This supports the result of other previous studies which have also revealed how people with different culture make use of these linguistic devices differently. However, the writer also believes that although culture plays an important role in determining the production of metadiscourse markers, the object of the current study, i.e. thesis abstracts, also helped influence the kind of markers that is used, especially in regards to endophoric and relational markers. Perhaps if a different kind of object is observed, for example other parts of a thesis, it might be possible that these two types of markers would also be frequently found.

\subsection{Suggestion}

As the closing to this research, some suggestions are given. For the first suggestion, seeing as this study is very limited in terms of scope and limitation, it would be better that future researches regarding metadiscourse not only compare between different cultures, but also from various disciplines as well. Furthermore, as has been briefly mentioned above, including other sections of a thesis would most likely yield very different result as opposed to only focusing on the abstract, since it is only a very small and simple part of an entire thesis. Last but not least, it is highly suggested that the students of Bunda Mulia University, more specifically the students from the English Language and Culture Department, be made more aware of the importance of using proper metadiscourse markers in academic writing. Although the current study shows that they have used more in terms of total frequency, it does not necessarily mean that it is necessary to use that many. Especially since some markers tend to be overused by them. Of course, it is the job of the lecturers to make sure that the students are able to use these linguistic devices more appropriately and efficiently. In the end, it is hoped that the result of this study may shed some light on the topic of metadiscourse in general, and that the

\footnotetext{
*Author(s) Correspondence:

E-mail: anugroho@bundamulia.ac.id
} 
students may be able to improve the overall quality of their writing.

\section{REFERENCES}

Anthony, L. 2018. AntConc (Version 3.5.6) [Computer Software]. Tokyo, Japan: Waseda University. Available from http://www.laurenceanthony.net/softwar e

Gholami, J., Nejad, S.R., and Pour, J.L. 2014. Metadiscourse Markers Misuses: a Study of EFL Learners' Argumentative Essays. Procedia - Social and Behavioral Sciences 98, 580 - 589.

Hyland, K. 1999. Talking to Students: Metadiscourse in Introductory Coursebooks. English for Specific Purposes 18, (1), 3 - 26.
Hyland, K. 2004. Disciplinary interactions: metadiscourse in L2 postgraduate writing. Journal of Second Language Writing, 13, 133 - 151.

Hyland, K. 2011. Academic Discourse. London: Continuum.

Hyland, K. and Tse, P. 2004. Metadiscourse in Academic Writing: A Reappraisal. Applied Linguistics, 25, (2), 156 - 177.

Khedri, M., Heng, C.S., and Ebrahimi, S.F. 2013. An exploration of interactive metadiscourse markers in academic research article abstracts in two disciplines. Discourse Studies, 15, (3), 319 - 331.

Ozdemir, N.O., and Longo, B. 2014. Metadiscourse Use in Thesis Abstracts: A Cross-cultural Study. Procedia Social and Behavioral Sciences 141, 59 -63 .

*Author(s) Correspondence:

E-mail: anugroho@bundamulia.ac.id 